\title{
The Tsunami Evacuation Route Planning by Using Tree Building Method
}

\author{
Khairul Syahmega ${ }^{1}$, Sofyan M. Saleh ${ }^{1}$, and T. Budi Aulia ${ }^{1}$ \\ Magister of Disaster Science, Syiah Kuala University, Jln Hamzah Fansuri No 4, Banda Aceh, \\ Indonesia \\ \{syahmega@gmail.com\}
}

\begin{abstract}
The use of the main road had caused the traffic and accident during the process of evacuation. Therefore, it is necessary to design some evacuation routes as an alternative to distributing the people. The study aimed to design the tsunami evacuation route by using tree building method for the people in Meuraxa sub-district, Banda Aceh, Aceh, Indonesia. To identify the appropriate evacuation method, about 377 questionnaires were distributed to the people in the region by using stratified random sampling. The road map published by Bappeda Aceh was used to study the road network. Results showed that the best evacuation method for the community was a vertical evacuation method. Since there were about 4 tsunami evacuation buildings (TEBs), the road networks were clustered into 4 and the destination node of each cluster was the TEB. A Dijkstra algorithm was built by using Ms.Excel application following the tree building method to find the shortest pathway of evacuations. The program was easy to run and could find the evacuation route quickly from any nodes. Then, the results of calculations were drawn as tree building of tsunami evacuation route.
\end{abstract}

Keywords: Tsunami, Evacuation Route, and Building Tree.

\section{Introduction}

The sub-district Meuraxa is located in Aceh Province, Indonesia. The region was totally destroyed by mega-tsunami in 2004. It can be influenced by the geographical location of the area along the coastal area where the Great Sumatran Fault or Semangko Fault occurred. Leone et.al [1] had reported that about 3 minutes after the first wave, the second high tsunami wave of $14.1 \mathrm{~m}$ had attacked the sub-district Meuraxa; its speed about $30 \mathrm{~km} / \mathrm{h}$ but as turbulent flow which was responsible to cause extreme destruction.

The population in this area has increased significantly after some years. Barus [2] provided that there was traffic during evacuation on $11^{\text {th }}$ April 2012, concentrated to the main road in this region, i.e. Sultan Iskandar Muda St., with the volume and capacity ratio of 0.54 . Therefore, they recommended to enlarge the road and to keep the road in a one-way direction during the evacuation. Recently, the number of population in sub-district Meuraxa is approximately 19,770; this number will increase every year, provided by (Central Bureau of Statistics Banda Aceh, 2017)[3]. The obstacle of evacuation should be solved. The objective of evacuation is to evacuate people in the right time, [4]. Sarusuk [5] stated that sufficient information about evacuation is necessary to guide the people during evacuation. To reduce the victim in the future, the tsunami evacuation route should be analyzed so that the people can evacuate quickly in a short time. The basic idea is that some evacuation routes to the tsunami evacuation buildings (TEBs) will distribute the people and reduce the traffic. Therefore, the objective of this study is to calculate the tsunami evacuation route for the people in sub-district Meuraxa by using the tree building method under the Dijkstra algorithm built up in Ms. Excel. 


\section{Method}

About 377 questionnaires were distributed to the people in Meuraxa sub-district following the stratified random sampling. This sub-district has 16 villages and the total population was approximately 19,770 people. The number of samples was determined by using Krejcie and Morgan table at the level significance of 5\%. A questionnaire consisted of 7 questions was designed to identify the best evacuation method for the people in the region. The mapped road published by Bappeda Aceh was used to draw the road network. The road chosen was the road with a minimum width of $3 \mathrm{~m}$.

\section{Result And Discussion}

\subsection{The Proposed Evacuation Method}

Based on questionnaire analysis, it is showed that approximately $5 \%$ of the people had no knowledge about tsunami disaster, even about $50 \%$ of the people did not have experience with this disaster. The past tsunami in 2004 had caused a high number of death people and most of the residents today had changed due to natural increase and migration. Dramatically, about 20\% of these people had no knowledge about the tsunami evacuation route.

Results also showed that about $48 \%$ of people would evacuate horizontally, $48 \%$ would evacuate vertically, and about $4 \%$ would stay at home for specific reasons. These specific reasons such as provided by Tuite \& Wolshon[6], elderly and homebound individuals called careless evacuation; their number was between $6-10 \%$. Results also showed that about $73 \%$ of people were vulnerable to tsunami consisted of children, women and elder people.

Considering the location of this region, the vertical evacuation method is better than the horizontal method. It is because the time needed to reach the safe area by the horizontal evacuation method was at least 22 minutes [7]. In addition, there were possibilities to have delayed reaction time up to 10 minutes due to (1) recognition and information level, (2) individual characteristic in taking immediate action, (3) infrastructure to provide warning, and (4) desire to collect items [8]. It is important to consider that the Acehnese people had a high desire to collect gold and money before evacuation. The mitigation efforts of tsunami disaster should appoint this situation to improve the people knowledge. Therefore, the proposed tsunami evacuation was designed as vertical evacuation method to tsunami evacuation building (TEB).

\subsection{Algorithm Dijkstra For Tsunami Evacuation Route}

The conventional calculation method for the shortest pathway seems to be not comfortable because it takes longer time and as the number of nodes increases, the calculation becomes more complicated. To solve this problem, a Dijkstra algorithm was constructed under Ms. Excel application to calculate the shortest route for tsunami evacuation route friendly and quickly. At this moment, the maximum number of nodes to be analyzed was 40 nodes notated with the capital alphabet from A to NA. 
Table 1. The Logical Functions of Dijkstra Algorithm

\begin{tabular}{|c|c|}
\hline Commands & Formulas \\
\hline Find the next shortest route & 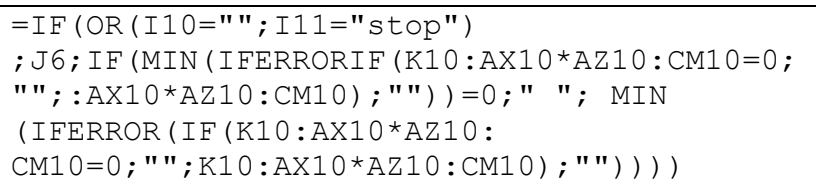 \\
\hline Read the matrix & 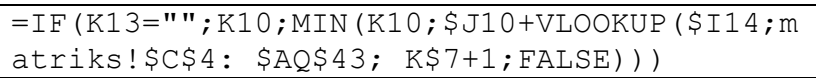 \\
\hline Read the addition of distance & 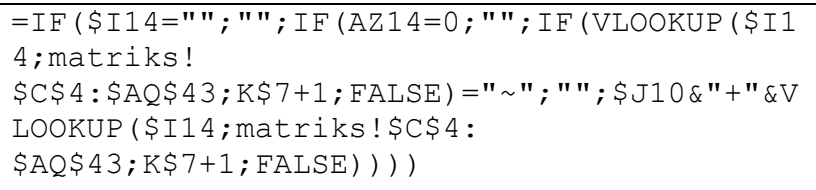 \\
\hline $\begin{array}{l}\text { Show the total distance of } \\
\text { selected route }\end{array}$ & 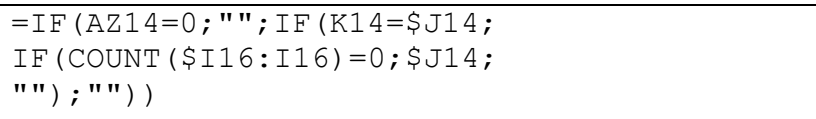 \\
\hline Show the selected node & 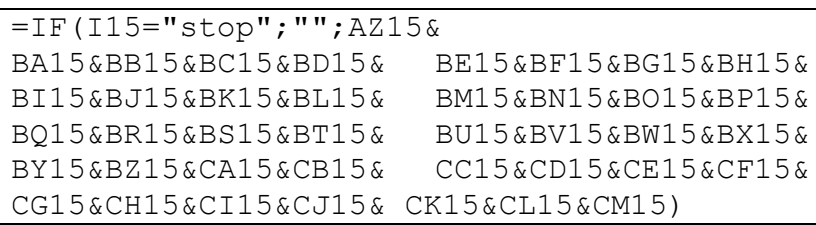 \\
\hline Find the evacuation route & $\begin{array}{l}\text { =IF (OR }(03=" " ; O 3=" ") ; " \text { Tidak ditemukan rute } \\
\text { jalur terpendek" } \\
\text {; LEFT }(\text { G166; LEN }(\text { G166)-3)) }\end{array}$ \\
\hline $\begin{array}{l}\text { Show the total distance of } \\
\text { evacuation route }\end{array}$ & 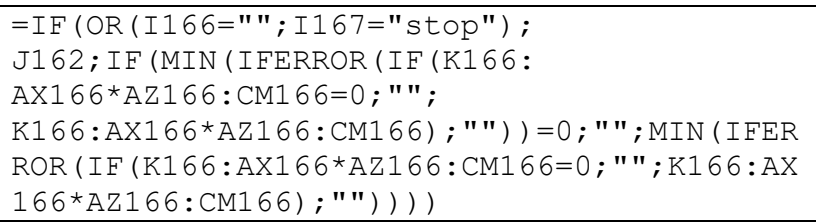 \\
\hline
\end{tabular}

To start the calculation, the first step is to fill the tabulated data of distance between nodes according to the road network. Then, this information should be moved to the layout worksheet under the syntax: copy-paste special-value. By filling the number of nodes and the origin node, the result of the calculation can be seen as the total distance and the route. The layout of the designed Dijkstra algorithm is shown in Figure 1and the combination of logical functions used were listed in Table 1. The algorithm was modified by using the Eq. (1).

$$
s_{p}=\sum_{i j \in L_{p}} s_{i j}
$$

Where $s_{p}$ is the distance from the origin node to the destination node (TEB) and $L_{p}$ is the distance between nodes in the network.

Recently, this approach is not considered multiple constrains that could affect the situation such as travel time, etc. However, the results of this analysis should be used as the basic 
information for the evacuation planning since the evacuation distance is one of the important parameters in a tsunami evacuation plan [4].

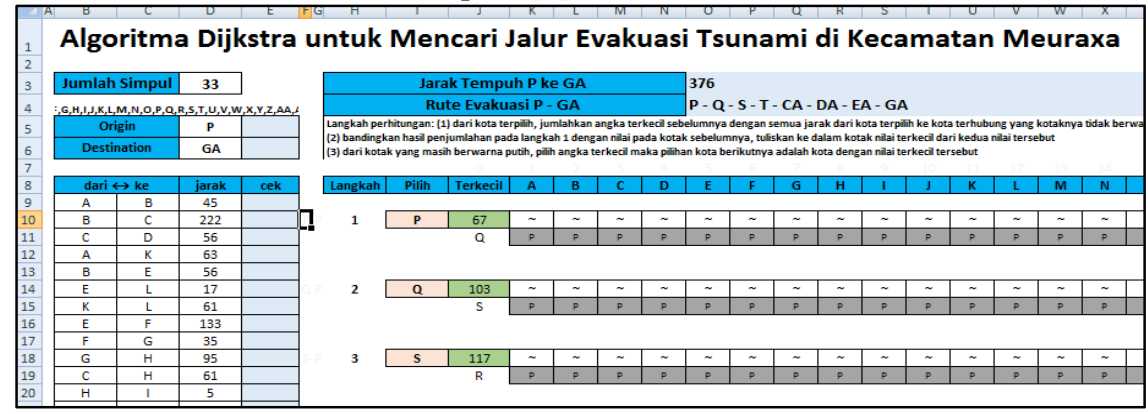

Figure 1. The worksheet layout of Algorithm Dijkstra

\subsection{The Determination of Road Cluster}

The determination of road cluster was done based on the road map published by Bappeda Aceh and the number of TEBs.

Table 2. The Distance Between Nodes in Cluster 1 and 2

\begin{tabular}{cccccc}
\hline \multicolumn{3}{c}{ Cluster 1 } & \multicolumn{3}{c}{ Cluster 2 } \\
\hline \multicolumn{2}{c}{ 21 nodes } & \multicolumn{3}{c}{ nodes } \\
\hline A & B & 75 & A & B & 45 \\
\hline B & C & 60 & B & C & 222 \\
\hline C & G & 47 & C & D & 56 \\
\hline C & D & 96 & A & K & 63 \\
\hline D & E & 13 & B & E & 56 \\
\hline E & F & 43 & E & L & 17 \\
\hline D & M & 57 & K & L & 61 \\
\hline N & M & 12 & E & F & 133 \\
\hline O & N & 58 & F & G & 35 \\
\hline O & P & 63 & G & H & 95 \\
\hline Q & O & 18 & C & H & 61 \\
\hline B & H & 26 & H & I & 5 \\
\hline H & I & 39 & I & J & 58 \\
\hline H & J & 94 & D & J & 61 \\
\hline J & K & 39 & F & M & 28 \\
\hline J & L & 5 & M & N & 18 \\
\hline L & Q & 30 & G & O & 36 \\
\hline L & R & 29 & L & U & 110 \\
\hline Q & S & 12 & K & R & 98 \\
\hline R & S & 64 & R & S & 14 \\
\hline S & T & 30 & P & Q & 67 \\
\hline R & U & 15 & Q & S & 36 \\
\hline & & & S & T & 15 \\
\hline & & & T & U & 45 \\
\hline & & & U & V & 17 \\
\hline & & & V & W & 48 \\
\hline & & & W & X & 21 \\
\hline & & & & \\
\hline
\end{tabular}




\begin{tabular}{ccc}
\hline X & BA & 57 \\
\hline AA & BA & 36 \\
\hline Z & AA & 34 \\
\hline Y & Z & 69 \\
\hline I & Z & 83 \\
\hline J & Y & 75 \\
\hline T & CA & 83 \\
\hline CA & DA & 32 \\
\hline V & DA & 83 \\
\hline DA & EA & 73 \\
\hline X & EA & 75 \\
\hline EA & GA & 70 \\
\hline FA & GA & 37 \\
\hline BA & GA & 78 \\
\hline AA & FA & 79
\end{tabular}

Meuraxa sub-district has 4 TEBs i.e. TEB1 in Gampong Alue Deah Teungoh, TEB2 in Gampong Deah Glumpang, TEB3 in Gampong Lambung, and TEB4 in Gampong Pie. Therefore, the road networks were clustered into 4 clusters.

The road network was built following the graph design with the characteristics of having a node name (A-NA) and having the distance information in term of a metre $(\mathrm{m})$. The example of the cluster is shown in Figure 2. The destinations of cluster 1, 2, 3, and 4 were TEB1, TEB2, TEB3, and TEB4, respectively.

Table 3. The Distance Between Nodes in Cluster 3 and 4

\begin{tabular}{|c|c|c|c|c|c|}
\hline \multirow{2}{*}{\multicolumn{3}{|c|}{$\begin{array}{l}\text { Cluster } 3 \\
27 \text { nodes }\end{array}$}} & \multicolumn{3}{|c|}{ Cluster 4} \\
\hline & & & & noc & \\
\hline $\mathrm{A}$ & $\mathrm{B}$ & 203 & $\mathrm{~A}$ & $\mathrm{D}$ & 31 \\
\hline $\mathrm{B}$ & $\mathrm{C}$ & 53 & $\mathrm{C}$ & $\mathrm{D}$ & 16 \\
\hline $\mathrm{C}$ & $\mathrm{D}$ & 39 & $\mathrm{D}$ & $\mathrm{G}$ & 69 \\
\hline $\mathrm{B}$ & $\mathrm{E}$ & 48 & B & $\mathrm{H}$ & 104 \\
\hline$E$ & $\mathrm{~F}$ & 59 & $E$ & $\mathrm{~F}$ & 26 \\
\hline$F$ & G & 54 & $\mathrm{~F}$ & $\mathrm{G}$ & 78 \\
\hline $\mathrm{G}$ & $\mathrm{H}$ & 36 & $\mathrm{G}$ & $\mathrm{H}$ & 73 \\
\hline $\mathrm{H}$ & $\mathrm{I}$ & 58 & $\mathrm{H}$ & $\mathrm{I}$ & 21 \\
\hline $\mathrm{A}$ & I & 47 & $\mathrm{~F}$ & $\mathrm{~J}$ & 27 \\
\hline $\mathrm{A}$ & $\mathrm{J}$ & 110 & $\mathrm{~J}$ & $\mathrm{O}$ & 55 \\
\hline I & $\mathrm{K}$ & 23 & $\mathrm{~J}$ & $\mathrm{~K}$ & 23 \\
\hline $\mathrm{J}$ & $\mathrm{K}$ & 45 & $\mathrm{~K}$ & $\mathrm{P}$ & 21 \\
\hline $\mathrm{J}$ & $\mathrm{L}$ & 302 & $\mathrm{~K}$ & $\mathrm{~L}$ & 42 \\
\hline $\mathrm{K}$ & $\mathrm{M}$ & 55 & $\mathrm{~L}$ & $\mathrm{Q}$ & 28 \\
\hline $\mathrm{L}$ & $\mathrm{M}$ & 113 & $\mathrm{~L}$ & $\mathrm{M}$ & 32 \\
\hline $\mathrm{L}$ & $\mathrm{W}$ & 65 & $\mathrm{M}$ & $\mathrm{R}$ & 23 \\
\hline $\mathrm{M}$ & $\mathrm{U}$ & 68 & $\mathrm{M}$ & $\mathrm{N}$ & 77 \\
\hline $\mathrm{V}$ & $\mathrm{W}$ & 83 & I & $\mathrm{N}$ & 31 \\
\hline $\mathrm{U}$ & $\mathrm{V}$ & 33 & $\mathrm{~N}$ & $\mathrm{~T}$ & 18 \\
\hline $\mathrm{W}$ & $Z$ & 114 & $\mathrm{~S}$ & $\mathrm{~T}$ & 260 \\
\hline $\mathrm{T}$ & $\mathrm{U}$ & 26 & $\mathrm{~T}$ & $\mathrm{X}$ & 118 \\
\hline $\mathrm{S}$ & $\mathrm{T}$ & 21 & $\mathrm{U}$ & $\mathrm{V}$ & 43 \\
\hline $\mathrm{R}$ & S & 45 & $\mathrm{~V}$ & $\mathrm{~W}$ & 47 \\
\hline
\end{tabular}




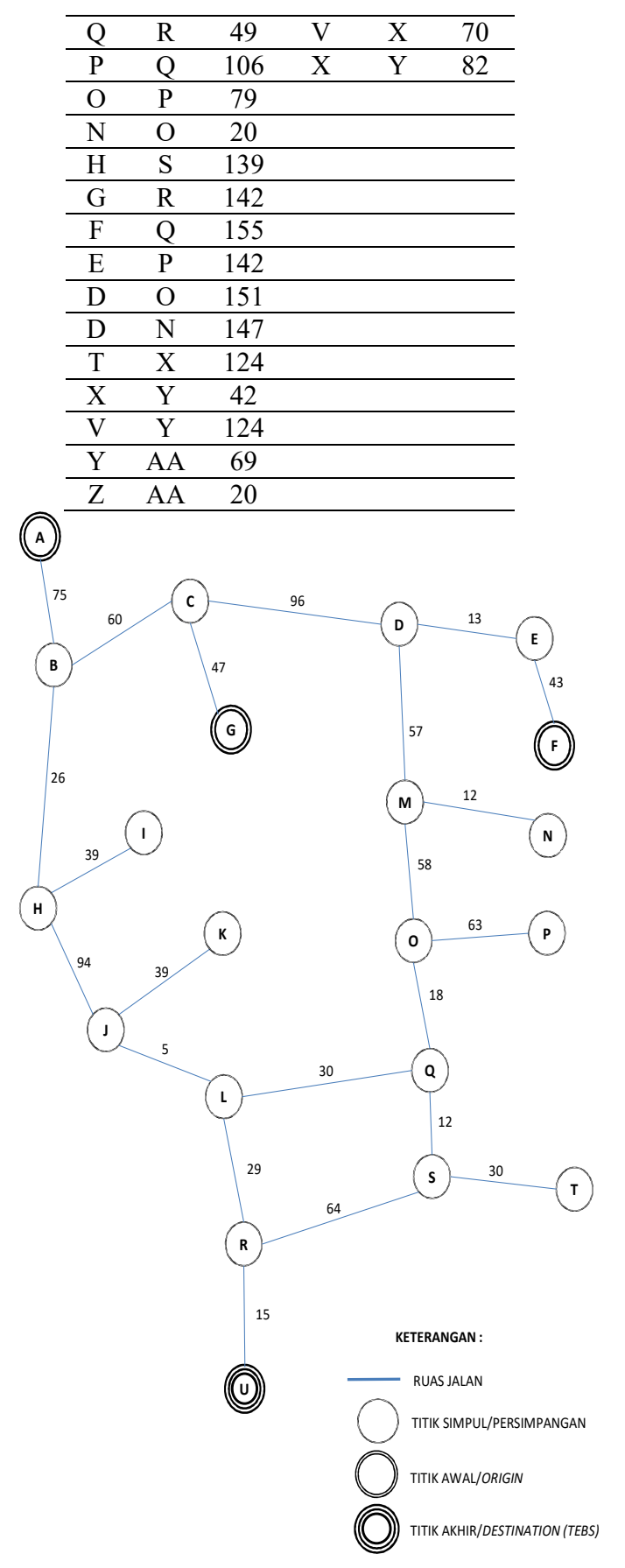

Figure 2. The road network in cluster 1 
After drawing the road network as can be seen in Figure 2, the data of distance between nodes were tabulated as it can be seen in Table 2 and 3. Results of alternative evacuation routes by using the Dijkstra Algorithm program designed is performed as the tree building in Figure 3 . The users could change the origin node depended on their home location or work place. [9] mentioned that the origin of the people probably from two places i.e. home or work place. So it explains also that it is a need to determine the shortest tsunami evacuation route from any possible nodes.

\subsection{The Tsunami Evacuation Route}

Results of recommended pathways for all clusters are shown in Table 4. These results were matched to the results of the conventional calculation method. However, the use of the conventional method has many disadvantageous such as takes longer time and causes boring or mistake. Lastly, the tree building in Figure 3 can be used to determine the evacuation routes.

The results of the shortest pathway for tsunami evacuation should be implemented to the evacuation map. As it was suggested by Scheer \& Varela [4] creating additional routes was one solution for an evacuation plan. The other solutions were enlarging existing route, increasing the capacity of existing shelter, and creating additional shelters. However, Shahabi \& Wilson [10] argued that it was not only enough for the routing algorithm to return a plan with small evacuation time but it should also assure that the prediction was realistic and the evacuation time was feasible. Therefore, a further study evacuation algorithm should work with multiple traffic models to optimize the solution.

Table 4. The Shortest Pathways Based on the Origin Nodes

\begin{tabular}{|c|c|c|c|}
\hline $\mathrm{ON}$ & $\mathrm{DN}$ & Route & $S_{p}(\mathrm{~m})$ \\
\hline \multicolumn{4}{|c|}{ Cluster 1} \\
\hline A & $\mathrm{U}$ & A-B-H-J-L-R-U & 244 \\
\hline G & $\mathrm{U}$ & G-C-B-H-J-L-R-U & 276 \\
\hline $\mathrm{F}$ & $\mathrm{U}$ & F-E-D-M-O-Q-L-R-U & 263 \\
\hline $\mathrm{T}$ & $\mathrm{U}$ & T-S-R-U & 109 \\
\hline \multicolumn{4}{|c|}{ Cluster 2} \\
\hline A & GA & A-K-R-S-T-CA-DA-EA-GA & 448 \\
\hline B & GA & B-E-L-U-V-W-X-BA-GA & 404 \\
\hline $\mathrm{C}$ & GA & C-H-I-Z-AA-BA-GA & 297 \\
\hline $\mathrm{D}$ & GA & D-J-I-Z-AA-BA-GA & 350 \\
\hline $\mathrm{Y}$ & GA & Y-Z-AA-BA-GA & 217 \\
\hline $\mathrm{O}$ & GA & O-G-H-I-Z-AA-BA-GA & 367 \\
\hline $\mathrm{N}$ & GA & $\begin{array}{l}\text { N-M-F-G-H-I-Z-AA-BA- } \\
\text { GA }\end{array}$ & 412 \\
\hline $\mathrm{CA}$ & GA & CA-DA-EA-GA & 175 \\
\hline $\mathrm{V}$ & GA & V-W-X-BA-GA & 204 \\
\hline $\mathrm{P}$ & GA & P-Q-S-T-CA-DA-EA-GA & 376 \\
\hline \multicolumn{4}{|c|}{ Cluster 3} \\
\hline A & $\mathrm{AA}$ & A-I-K-M-U-V-Y-AA & 419 \\
\hline $\mathrm{J}$ & $\mathrm{AA}$ & J-K-M-U-V-Y-AA & 394 \\
\hline B & $\mathrm{AA}$ & B-E-F-G-H-S-T-X-Y-AA & 592 \\
\hline $\mathrm{D}$ & $\mathrm{AA}$ & $\begin{array}{l}\text { D-C-B-E-F-G-H-S-T-X-Y- } \\
\text { AA }\end{array}$ & 684 \\
\hline $\mathrm{N}$ & AA & N-O-P-Q-R-S-T-X-Y-AA & 555 \\
\hline
\end{tabular}




\begin{tabular}{ccll}
\multicolumn{2}{c}{ Cluster 4} & & \\
A & Y & A-D-G-H-I-N-T-X-Y & 443 \\
E & Y & E-F-J-K-L-M-N-T-X-Y & 445 \\
O & Y & O-J-K-L-M-N-T-X-Y & 447 \\
S & Y & S-T-X-Y & 460 \\
B & Y & B-H-I-N-T-X-Y & 374 \\
\hline
\end{tabular}

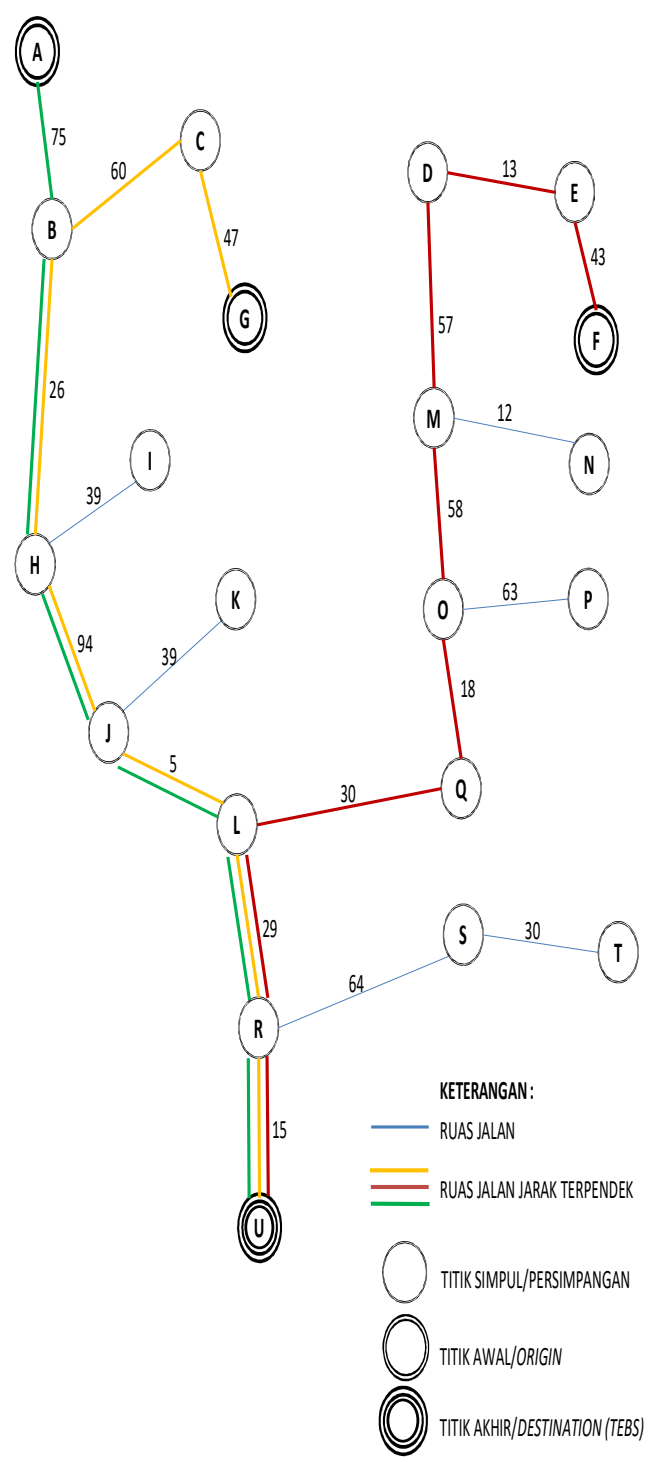

Figure 3. The tree building in cluster 1 


\section{Conclusion}

The new approaching of using Dijkstra algorithm built in Ms. Excel had offered comfortable way for the users to find the tsunami evacuation route easily and quickly. The simulation of changing of origin nodes $(\mathrm{ON})$, as well as destination nodes (DN), can be run as many as possible. It is expected to provide some alternative tsunami evacuation routes for the residents of sub-disctricMeuraxa that will build up into a tsunami evacuation map.

\section{REFERENCES}

[1] F. Leone, F. Lavigne, R. Paris, J. C. Denain, and F. Vinet, "A spatial analysis of the december 26th, 2004 tsunami-induced damages: Lessons learned for a better risk assessment integrating buildings vulnerability," Appl. Geogr., vol. 31, pp. 363-375, 2011.

[2] E. S. Barus, "Kajian jalur evakuasi bencana gempa bumi berpotensi tsunami berbasis masyarakat (studi kasus kecamatan Baiturrahman kota Banda Aceh,” Universitas Syiah Kuala. Banda Aceh, 2013.

[3] BPS Kota Banda Aceh, "Kecamatan Meuraxa dalam angka 2017," 2017. [Online]. Available: https://bandaacehkota.bps.go.id/publication/2017/09/27/ceb0e7339a79846bd8637634/kecamata n-meuraxa-dalam-angka-2017.html.

[4] dan E. G. Scheer, S.J., Varela, V., “A generic framework for tsunami evacuation planning,” Phys. Chemestry Earth, vol. 49, pp. 79-91, 2012.

[5] J. H. Saruksuk, "Konsep jaringan jalan pada kota yang rawan bencana gempa dan tsunami (studi kasus Kota Sibolga)," Universitas Dipenogoro, Semarang, 2006.

[6] P. M. Tuite and B. Wolshon, "Evacuation transportation modeling: An overview of research, development and practice," Transp. Res. Part C, vol. 27, pp. 25-45, 2013.

[7] H. Yuzal, MURP, K. Kim, PhD, P. Pant, PhD, and E. Yamashita, MURP, "Tsunami evacuation buildings and evacuation planning in Banda Aceh, Indonesia," J. Emerg. Manag., vol. 15, no. 1, p. 49, Jan. 2017.

[8] S. Park, J. W. van de Lindt, R. Gupta, and D. Cox, "Method to determine the locations of tsunami vertical evacuation shelters," Nat. Hazards, vol. 63, no. 2, pp. 891-908, Sep. 2012.

[9] J. H. Lambert et al., "Understanding and managing disaster evacuation on a transportation network," Accid. Anal. Prev., vol. 50, pp. 645-658, Jan. 2013.

[10] K. Shahabi and J. P. Wilson, "CASPER: Intelligent capacity-aware evacuation routing," Comput. Environ. Urban Syst., vol. 46, pp. 12-24, Jul. 2014. 